\title{
EDITORIAL
}

\section{THE LOOMING ENVIRONMENTAL CRISIS}

As governments around the world attempt to prop up our ailing economies by developing large stimulus packages in an attempt to restore and promote new growth and development, it appears that both health and environment have taken a back seat when in fact they should still be at the forefront of government policy. In this issue of the MJM we have assembled a collection of articles that discuss and investigate the close relationship that exists between health and environment, and we argue that as government officials attempt to restore our nation's economy, they should not overlook the important alliance that coexists between environment, the health of a nation's workforce and their GDP (1).

The policies of our predecessors have already left the world committed to many upcoming years of global warming, a predicament which will only be relieved by drafting and implementing critical policies in the coming years which aim to deter and prevent further climate change $(2,3)$. In fact, even modest increases in temperature have been associated with significant elevations in morbidity and mortality, especially in the most vulnerable members of society, the young and old $(2,4)$. Thus, as the Canadian population ages, with one in five expected to reach 65 years of age by 2026 (5), and as the lifespan of immunocompromised patients is prolonged thanks to the great feats of contemporary medicine, we must find a way to palliate the imminent increase in mortality in these most vulnerable groups due to the consequences of our deteriorating environment. For example, the World Health Organization estimated that there were at least 27,000 more deaths in Europe over the summer of 2003 relative to the previous years which was associated with unusually elevated temperatures recorded during the same time period (6). If such an alarming event could occur in a relatively well-endowed region of the globe, the repercussion of human-induced climate derangement on casualties in the third-world, although difficult to document, likely reaches pandemic proportions in an era where the scarcity of medical aid and adequate water for human consumption is deplorable.

As the 'mercury rises,' a paralleled increase in the incidence of food-, water- and vectorborne illnesses has also been documented, and these have been at least partially attributed to a number of deaths in recent years $(7,8)$. Among the changes being observed in the Canadian climate is a rise in the incidence of violent storms, which can lead to temporary 'pulses' in local water contaminants and bacteria that increases the risk of becoming ill (9-11). Even more worrisome is that this only appears to be the beginning since the global shift in climate and temperatures are expected to worsen in the coming years, since the world appears to be committed to several more decades of warming (9).

An equally worrying trend has also been observed in air quality and the potentially fatal exacerbation of several chronic health conditions including asthma, chronic obstructive pulmonary disease (COPD), lung cancer and cardiopulmonary-associated conditions, to name a few (12). Although the etiology of many of these conditions is complex and is likely attributable to other causes at present, there is no doubt those acute changes in outdoor air quality, such as smog episodes, increases patient morbidity and mortality. Despite the existence of strict Canadian policies with regards to the use of fossil fuels, other nations have lagged behind and are severely suffering from their lack of intervention (13-15). Moreover, these bothersome trends are unlikely to disappear anytime soon, as these developing nations are also struggling against the slumping global economy and are trying to rapidly restore their own economies without any long-term regards to the future consequences.

As governments around the world attempt to implement new policies that aim to stimulate the global economy, it is worth asking where the environment fits into these plans. For example, back in 1992, the Kyoto protocol brought the hope of governmental engagement for a better planet. However, the emerging dichotomy between keeping the economy afloat and respecting the clauses of the treaty have lead to the controversial ratification of the allegiance to the Kyoto treaty by some of the signatories, such as the European Union and Canada, to name a couple. However, given that a nation's economic status is dependent on the wellness of their workforce, the impact of environment on health should not be overlooked. More importantly, is the healthcare system ready in terms of financial and maind'oeuvre resources, to tackle the increase incidence of illness related to environmental deterioration? As such, we urge our readers to consider the importance of developing governmental policies that not only address the present economic crisis, but we would also encourage you to consider the long-term benefits and advantages that might be achieved in both health and environment through the implementation of sustainable programs. 


\section{REFERENCES}

1. Stern N. Stern Review on the Economics of Climate Change. London, UK: HM Treasury. Available at: http://www.hmtreasury.gov.uk/stern_review_report.htm; 2006.

2. IPCC. Climate Change 2007: Impacts, Adaptation and Vulnerability. Contribution of Working Group II to the Fourth Assessment Report of the Intergovernmental Panel on Climate Change: Working Group II. Cambridge, UK: Cambridge University Press; 2007.

3. Patz J, Campbell-Lendrum D, Holloway T, Foley J. Impact of regional climate on human health. Nature. 2005;438(7066):31017.

4. Ebi KL SJ, Burton I, Scheraga J. Some lessons learned from public health on the process of adaptation. Mitigation and Adaptation Strategies for Global Change 2006;11:607-620.

5. Government of Canada CsAP, p.1, Minister of Public Works and Government Services Canada 2002, accessed online March 09, h t t p : // w w w . phac-as pc.gc.ca/s e n i or saines/pubs/fed_paper/pdfs/fedpager_e.pdf.

6. World Health Organization $\mathrm{CaH}^{-}$, Fact sheet, July 2005, Accessed online March 09, http://www.who.int/globalchange/news/fsclimandhealth/en/inde x.html.

7. Confalonieri U MB, Akhtar R, Ebi KL, Hauengue M, Kovats RS, et al. Human Health. In: Parry ML, Canziani OF, Palutikof JP, van der Linden PJ, Hansson CE, editors. Climate Change 2007: Impacts, Adaptation and Vulnerability. Contribution of Working Group II to the Fourth Assessment Report of the Intergovernmental Panel on Climate Change. Cambridge, U.K.: Cambridge University Press, 2007; p. 391-431.
8. Fleury M, Charron DF, Holt JD, Allen OB, Maarouf AR. A time series analysis of the relationship of ambient temperature and common bacterial enteric infections in two Canadian provinces. International journal of biometeorology. 2006 Jul;50(6):385-91.

9. Intergovernmental Panel on Climate Change (IPCC). Climate Change 2007: The Physical Science Basis. Summary for Policymakers. Contribution of Working Group I to the Fourth Assessment Report. Cambridge U.

10. Charron D, Thomas M, Waltner-Toews D, Aramini J, Edge T, Kent R, et al. Vulnerability of waterborne diseases to climate change in Canada: A review Journal of Toxicology and Environmental Health - Part A - Current Issues. 2004;67(2022):1667-77.

11. Charron D, Waltner-Toews D, Maarouf A. A Synopsis of Known and Potential Diseases and Parasites Associated with Climate Change, Paper. No. 154. Sault Ste. Marie, ON: Ontario Ministry of Natural Resources, Ontario Forestry Research Institute; 2003.

12. Chen H GM, Villeneuve PJ. A Systematic Review of Relation between Long-term Exposure to Ambient Air Pollution and Chronic Diseases. Reviews On Environmental Health. 2008;23:243-96.

13. Shandilya KK KM, Gupta AB. Suspended particulate matter distribution in rural-industrial Satna and in urban-industrial South Delhi. Environ Monit Assess. 2007;128:431-45.

14. Romieu I MF, Sienra-Monge JJ, Huerta J, Ruiz VS, White MC et al. Effects of urban air pollutants on emergency visits for childhood asthma in Mexico City. Am J Epidemiol. 1995;141:546-53.

15. Fleischmann MaM, R. Ambient Air Level Trends for Pollutants in Large Canadian Cities . 1-32. 6-19-2003. University of Guelph. 9-8-2008.
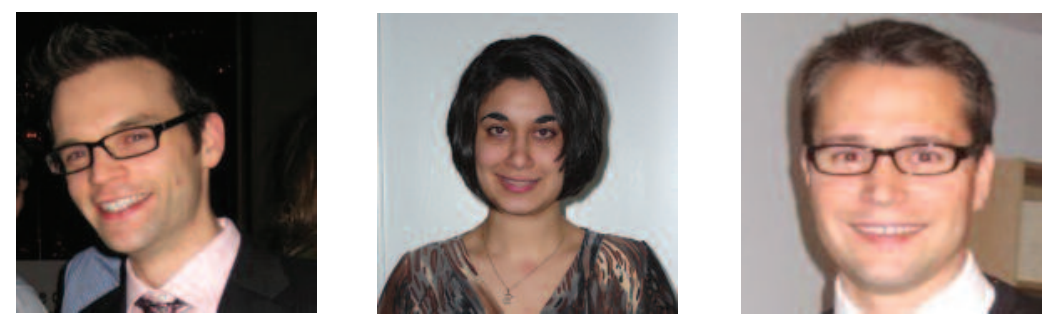

Russell Brown (M.D.C.M. 2011) has previously served as a senior editor with the MJM and has a particular research interest in the neurobiology of obesity, and trying to elucidate the various role(s) of brain-derived adipokines. He received a B.Sc (Hons) in Biochemistry and Molecular Biology (2003) and earned a PhD in Physiology and Biophysics (2007) both from Dalhousie University (Halifax NS).

Charlotte Kfoury (M.D.C.M. 2011) graduated from McGill University in 2007 with an Honours degree in Biochemistry. Her research interests lie in regenerative cell therapies and neurosciences.

Paul D. Simoncic (M.D.C.M. 2011) competed his Ph.D. in Biochemistry in 2004, focusing on monocyte development and activation. He pursued a Post-Doctoral fellowship at the Ontario Cancer Center where he studied mechanisms of bone cell function and differetiation. He is the recipient of a CIHR studentship, a NCIC Terry Fox Scholarship, and a Leukemia and Lymphoma Society of Canada grant. He has authored several primary papers and reviews in these fields. 